$10-1-1979$

\title{
The Concept of Function and the Basis of Regulatory Interests under Functional Choice-of- Law Theory: The Significance of Benefit and the Insignificance of Intention
}

Gregory S. Alexander

Cornell Law School, gsa9@cornell.edu

Follow this and additional works at: http://scholarship.law.cornell.edu/facpub

Part of the Conflicts of Law Commons, and the Legal History, Theory and Process Commons

\section{Recommended Citation}

Alexander, Gregory S., "The Concept of Function and the Basis of Regulatory Interests under Functional Choice-of-Law Theory: The Significance of Benefit and the Insignificance of Intention" (1979). Cornell Law Faculty Publications. Paper 256.

http://scholarship.law.cornell.edu/facpub/256 


\title{
THE CONCEPT OF FUNCTION AND THE BASIS OF REGULATORY INTERESTS UNDER FUNCTIONAL CHOICE- OF-LAW THEORY: THE SIGNIFICANCE OF BENEFIT AND THE INSIGNIFICANCE OF INTENTION
}

\author{
Gregory S. Alexander*
}

[T]he court needs to be aware that the concept of purpose is not simple. ${ }^{1}$

REENT literature ${ }^{2}$ and judicial opinions ${ }^{3}$ have recognized the Dneed for control and consistency in choice of law. Although the formulation of choice-of-law theory in terms of the states' interests in the conflicting rules at issue has gained wide acceptance, the courts have been unable to agree upon criteria for determining when a state has a valid interest in dispute resolution. ${ }^{4}$ Moreover, courts frequently appear all too eager to use contemporary choice-of-law analysis to justify local regulation of multistate disputes despite

\footnotetext{
* Associate Professor of Law, University of Georgia School of Law. Earlier drafts and the present version of this article owe much to the helpful comments of several individuals, especially Julian McDonnell, Michael Wells, John McCoid, Stephen Saltzburg, George
} Rutherglen, and George Fletcher.

' H. M. Hart \& A. Sacks, The Legal Process 1413 (tent. ed. 1958).

'See, e.g., Shapira, "Grasp All, Lose All": On Restraint and Moderation in the Reformulation of Choice of Law Policy, 77 Colum. L. REv. 248 (1977); Silberman, Shaffer v. Heitner: The End of an Era, 53 N.Y.U.L. REv. 33, 88 n.286, 97-99 (1978); Note, After Hurtado and Bernhard: Interest Analysis and the Search for a Consistent Theory for Choice-of-Law Cases, 29 STAN. L. REv. 127 (1976). Expressions of the need for control have been especially prominent in connection with questions about the appropriateness and fairness of decisions to apply local substantive law that impose broad liability on defendants when the local contacts are no more substantial than a resident plaintiff. See, e.g., Rosenthal v. Warren, 475 F.2d 438 (2d Cir.), cert. denied, 414 U.S. 856 (1973). For a critical discussion of this decision, see Leflar, Choice of Law: A Well-Watered Plateau, Law \& ConTEMP. ProB., Spring 1977, at 10, 20-21.

3 See, e.g., Neumeier v. Kuehner, 31 N.Y.2d 121, 286 N.E.2d 454, 335 N.Y.S.2d 64 (1972); Tooker v. Lopez, 24 N.Y.2d 569, 583-85, 249 N.E.2d 394, 403-04, 301 N.Y.S.2d 519, 531-33 (1969) (Fuld, C.J., concurring).

- The guest-statute cases from the New York Court of Appeals form a familiar line of decisions illustrating lack of consistency in analysis of interests. See Neumeier v. Kuehner, 31 N.Y.2d 121, 286 N.E.2d 454, 335 N.Y.S.2d 64 (1972); Tooker v. Lopez, 24 N.Y.2d 569, 249 N.E.2d 394, 301 N.Y.S.2d 519 (1969); Dym v. Gordon, 16 N.Y.2d 120, 209 N.E.2d 792, 262 N.Y.S.2d 463 (1965); Babcock v. Jackson, 12 N.Y.2d 473, 191 N.E.2d 279, 240 N.Y.S.2d 743 (1963).

Difficulties with this basic question persist in more recent decisions. The finding of a California interest in Hurtado v. Superior Court, 11 Cal. 3d 574, 522 P.2d 666, 114 Cal. Rptr. 106 (1974), for example, has drawn considerable criticism. See, e.g., Weintraub, The Future of Choice of Law for Torts: What Principles Should Be Preferred?, LAw \& ConteMP. ProB., Spring 1977, at 146, 154-55. For a discussion of Hurtado, see note 83 infra. 
insubstantial local relationships. ${ }^{5}$ The inconsistency and local bias both stem from the lack of a coherent theory for discerning the existence of a state interest.

Fundamental to developing a coherent theory of interests is the concept of the purpose or "function" of rules. ${ }^{6}$ Under existing "functional" choice-of-law theory, ${ }^{7}$ a court considers the functions of competing rules to determine whether their application in the particular case would advance these functions. Functions are equated with the reasons for a rule's enactment. To eliminate inconsistency and abuses under the functional theory, some commentators suggest that courts restrict the evaluation of a state's interest to those objectives actually articulated by the rule's makers. ${ }^{8}$

This article begins with the idea, also advanced by others, ${ }^{9}$ that the authority to regulate multistate disputes is a resource that must be allocated among competing states in a rational manner. Rational allocation requires an assessment of the effect upon a state of denying the authority to regulate a dispute. If such denial would affect a state adversely, that state may be considered legitimately interested. In making this determination, courts should focus when possible upon the actual effects that rules produce or advance. Such effects, when known, should form the basis for state interests even when the effects cannot be linked exclusively to the articulated objectives of the rulemakers. Indeed, when the goals and effects of a rule do not coincide, effects should be determinative. ${ }^{10}$

${ }^{5}$ See, e.g., Rosenthal v. Warren, 475 F.2d 438 (2d Cir.), cert. denied, 414 U.S. 856 (1973); Bernhard v. Harrah's Club, 16 Cal. 3d 313, 546 P.2d 719, 128 Cal. Rptr. 215, cert. denied, 429 U.S. 859 (1976); Schwartz v. Consolidated Freightways Corp., 300 Minn. 487, 221 N.W.2d 665 (1974). See generally Weintraub, supra note 4, at 159-62.

- See Currie, Conflict, Crisis, and Confusion in New York, 1963 Duke L.J. 1, 29 n.91, reprinted in B. CuRRIE, Selected Essays on the Conflict of Laws 690, $717 \mathrm{n.91}$ (1963).

"In the idiom of choice-of-law scholarship, "functional analysis" has usually been identified with the theory, a variation of interest analysis, of Professors von Mehren and Trautman and Professor Weintraub. See A. von Mehren \& D. Trautman, The Law of Multistate Problems $76-79$ (1965); R. Weintraub, Commentary on the Conflict of Laws 6-7 (1971). In this article the term is used in a more generic sense, referring to all theories that take for granted the relevance of "policies" and "interests" of the states involved in the dispute. I have selected "functional analysis" in preference to "interest analysis" in an effort to avoid confusion with the theory of interest analysis prominent in American legal theory. See R. Pound, Outlines of Lectures on Jurisprudence 95-114 (5th ed. 1943); Pound, A Survey of Social Interests, 57 HARv. L. REv. 1 (1943); Pound, A Theory of Social Interests, in 15 PAPERS AND Proceedings of the American Sociological Society 16 (1921). Moreover, the emphasis on "function" more accurately describes the central feature of the theory.

${ }^{3}$ See R. WeINTRAUB, supra note 7, at 201-02, 242; Shapira, supra note 2, at 261-65.

- See, e.g., Baxter, Choice of Law and the Federal System, 16 STAN. L. Rev. 1, 6-7 (1963).

${ }^{10}$ This article does not deal explicitly with the resolution of a true conflict, i.e., how to 
I. The Theoretical Foundations of Functional Choice-of-Law analysis-The Choice-of-Law Process as Rule Interpretation

Most contemporary choice-of-law theories share at least two premises. First, in adjudicating a dispute arising out of a multistate transaction, a court must choose between competing legal rules rather than between competing jurisdictions. "The second premise follows from the first: a court should base its choice at least in part upon an analysis of the policies embodied in the competing rules. ${ }^{12}$ A state has a legitimate reason to have its rule applied to a dispute if such application would further the policies underlying the rule. Although theorists disagree on the weight to be assigned the claims of competing states and on the method of proceeding when both states have legitimate claims to regulatory authority, ${ }^{13}$ the extent of agreement on these two premises makes reference to a "new orthodoxy"14 in choice-of-law theory meaningful.

proceed when both states have legitimate interests in seeing their rules applied. See Currie, Survival of Actions: Adjudication Versus Automation in the Conflict of Laws, 10 STAN. L. Rev., 205, 239-40 (1958), reprinted in B. CuRRIE, supra note 6, at 128, 161-62. Rather, the article deals with the threshold issue of the proper manner for determining if a state interest exists. Some of this article's analysis, however, is relevant to the resolution of true conflicts. See notes 70-83 infra and accompanying text.

"The historical shift from a jurisdiction-selecting analysis to the current emphasis on the content of the specific rules at issue is described in von Mehren, Recent Trends in Choice-ofLaw Methodology, 60 CoRnell L. REv. 927, 928-41 (1975).

${ }_{12}$ Currie, Notes on Methods and Objectives in the Conflict of Laws, 1959 Duke L.J. 171, 178 , reprinted in B. CuRrse, supra note 6, at 177, 183-84:

[T] $\mathrm{T}$ court should, first of all, determine the governmental policy expressed in the law of the forum. It should then inquire whether the relation of the forum to the case is such as to provide a legitimate basis for the assertion of an interest in the application of that policy....

If necessary, the court should similarly determine the policy expressed by the foreign law, and whether the foreign state has an interest in the application of its policy.

Id. It should be noted also that this formulation explicitly adopts a bias favoring application of forum substantive law.

is Brainerd Currie consistently argued that a court ought not to engage in a process of weighing interests since that weighing involves an exercise of considerable political responsibility that courts are ill-prepared to exercise. See, e.g., Currie, supra note 12, at 176-77, reprinted in B. CURRIE, supra note 6, at 181-82. More recently, several writers bave agreed with this view, see, e.g., Sedler, The Governmental Interest Approach to Choice of Law: An Analysis and a Reformulation, 25 U.C.L.A. L. REv. 181 (1977), while others have dissented, see, e.g., Hill, Governmental Interest and the Conflict of Laws-A Reply to Professor Currie, 27 U. CHI. L. REv. 463, 474-77 (1960). Disagreement on this matter is also reflected in judicial opinions. Compare, e.g., Lilienthal v. Kaufman, 239 Or. 1, 395 P.2d 543 (1964) (majority opinion), with id. at 18, 395 P.2d at 550 (dissenting opinion).

14 The phrase is drawn from Shapira, supra note 2 , at 248 , who concludes, as does this article, that one can meaningfully speak of a single modern conventional theory of choice of 
These shared premises developed within the context of a fundamental recasting of the choice-of-law problem. Traditional theory had approached the problem in terms of determining the limitations of state legislative jurisdiction-that is, power-to create private rights. ${ }^{15}$ Preoccupied with territorial considerations, traditional theory viewed the choice-of-law problem as unique, requiring its own principles for analysis. Revisionists sought to place the choiceof-law problem within a more familiar framework. They viewed it essentially as a special instance of interpretation of statutes and construction of common-law rules. ${ }^{16}$ Determining whether to apply state $X$ 's rule or state $Y$ 's required interpretation and construction of those rules. Just as in the ordinary nonconflicts case, the court must interpret and construe a local statute to determine whether the terms should be read to fit the factual circumstances immediately presented. The only difference in a conflict-of-laws case is that the court has not only its own statute to consider but also a foreign rule inconsistent with its own. The foreign rule is relevant simply because some aspects of the dispute involve another jurisdiction.

To illustrate this formulation of the problem, consider two hypothetical cases. ${ }^{17}$ In the first, $D$ agrees for $\$ 30$ to drive $P$ in $D$ 's car to some destination. $D$ previously has never carried passengers in his

law. This conclusion rests on the observation that despite the differences in shades attached by various commentators, contemporary choice-of-law doctrine has but a single color: a fundamental commitment to a teleological perspective. The intellectual heritage of modern choice-of-law thought is discussed in A. Shapira, The INTEREst Approach to Choice of Law 61-67 (1970).

$151 \mathrm{~J}$. Beale, A Treatise on the Conflict of Laws 1-2, 46 (1935).

is An early example of this recharacterization of the choice-of-law problem is Hancock, Choice-of-Law Policies in Multiple Contact Cases, 5 U. Tononto L.J. 133 (1943). Brainerd Currie subsequently adopted this characterization. His only thorough attempt at resolution of a choice-of-law problem through the process of statutory construction was in Currie \& Lieberman, Purchase-Money Mortgages and State Lines: A Study in Conflict-of-Laws Method, 1960 Duke L.J. 1, reprinted in B. CuRRIE, supra note 6, at 376. See also R. WeINTRAuB, supra note 7, at 231-32; Hancock, Three Approaches to the Choice-of-Law Problem: The Classificatory, the Functional, and the Result-Selective, in XXTH CENTURY COMPARative and Conflicts Law 365, 367, 371, 375, 377 (1961); Hancock, Torts Problems in Conflict of Laws Resolved by Statutory Construction: The Halley and Other Older Cases Revisited, 18 U. ToRonto L.J. 331 (1968) [hereinafter cited as Hancock, Torts Problems in Conflict of Laws]; Sedler, supra note 13, at 201 n.118. Supporters of this view assume that the Supreme Court adopted the same technique in an analogous context in Lauritzen v. Larsen, 345 U.S. 571, 578-79 (1953). See R. Cramton, D. Currie \& H. Kay, Conflict of Laws: CASES-COMMENTS-QUESTIONS 245 (2d ed. 1975).

17 The following hypothetical problems are based on Lemieux v. Bedard, [1953] 4 D.L.R. 252, aff'g [1952] 4 D.L.R. 421, discussed in Hancock, Torts Problems in Conflict of Laws, supra note 16, at $331-40$. 
car for compensation. In the course of the trip $P$ is injured due to $D$ 's negligence. The entire transaction as well as the domicile of both parties is located in a single jurisdiction. That jurisdiction has a statute providing that the driver of a car shall not be liable for damages resulting from personal injuries to a passenger in the car unless the vehicle is "operated in the business of carrying passengers for compensation." $D$ contends that this statute completely bars recovery; consequently, the court must decide whether $D$ 's car is a vehicle "operated in the business of carrying passengers for compensation." Resolution of the issue requires interpretation and construction based on the policies underlying the statute as well as its words.

In the second example, $P$ and $D$, both domiciled in state $Q$, make plans to move to neighboring state $O$ where they will live together. A few days before their departure $P$ is injured while riding as a gratuitous passenger in a car negligently driven by $D$. According to a statute of $Q, D$ would be liable for the damages. $P$, however, brings an action for damages in $O$, their new domicile, which has a statute identical to that mentioned in the first example. If the court in $O$ applies its own statute, $P$ cannot recover from $D$. Clearly $P$ would prefer that the rule of $Q$ be applied, permitting recovery. Under these circumstances the court must choose between the two rules; at issue is the basis upon which the choice shall be made.

Theorists of the new orthodoxy find that the two cases present essentially the same problem..$^{18}$ In both cases, through an examination of the statutes' language and policies, the court must determine whether the statutes "cover" the immediate dispute. The method for resolving this issue in the first case-the process of statutory interpretation and construction-therefore may be used equally well in the second. ${ }^{19}$

The emergence of instrumental legal theory aided the recasting of the choice-of-law problem as a matter of statutory interpretation. ${ }^{20}$ Under this theory, legislation was conceived of as an instru-

18 See Hancock, Torts Problems in Conflict of Laws, supra note 16, at 331-32.

"See id.

20 The instrumental conception, which is the intellectual foundation of functional analysis, is described in von Mehren, supra note 11, at 941, and in A. SHAPIRA, supra note 14, at 61-67. Intellectual legal history recently bas produced a considerable body of literature on the emergence of instrumentahism as the dominant perspective. See, e.g., Horwitz, The Emergence of an Instrumental Conception of American Law, in 5 PERSPECTIVEs IN AMERICAN HisTORY 287 (1971); White, From Sociological Jurisprudence to Realism: Jurisprudence and 
ment with which lawmakers achieve social ends chosen among alternatives. ${ }^{21}$ Statutory interpretation therefore necessarily required attention to the ends that a statute was designed to pursue. The meaning of any rule, and thus its scope of application, could be revealed only as the purposes or functions of the rule were identified and their relevance to a given set of circumstances examined. ${ }^{22}$ Typically employed to determine the subject-matter scope of a statute (does a statute prohibiting "vehicles" in the park include bicycles and baby carriages?), conflicts theorists used the instrumental approach to interpretation to determine the geographical reach of statutes.

It is difficult to overestimate the importance to the new choiceof-law orthodoxy of this conception of legal rules. Other views of legislation would have rendered impossible the characterization of the choice-of-law process as one of rule interpretation. A literal approach that ignored the statutes' intended purposes when determining the "meaning" of statutes, ${ }^{23}$ for example, usually would lead to absurd results in a choice-of-law problem. Written as they usually are in universal terms, ${ }^{24}$ statutes interpreted literally might be read

Social Change in Early Twentieth-Century America, 58 VA. L. REv. 999 (1972). See also R. DWorkin, Taking Rights Seriously 4 (1977).

21 Reflective of the instrumental view are the teaching materials of Henry Hart and Albert Sacks. See H. M. HART \& A. SACKs, supra note 1. Any discussion of the prevailing theory of interpretation and the theory of legislation that it presupposes must begin with reference to this work, which aptly expresses the instrumental view in the following passage: "Every statute must be conclusively presumed to be a purposive act. The idea of a statute without an intelligible purpose is foreign to the idea of law and inadmissible." Id. at 1156.

22 The purposive theory of meaning is classically expressed in Fuller, Positivism and Fidelity to Law-A Reply to Professor Hart, 71 HARv. L. Rev. 630 (1958). Fuller subsequently elaborated and refined the theory in L. FuLLER, THE MORALTTY OF LAW 145-51 (rev. ed. 1969). The purposive theory of meaning is adopted so conventionally as the foundation for statutory interpretation that Professor Hancock, in referring to the theory, observed that the "statement is too trite to require citation." Hancock, Torts Problems in Conflict of Laws, supra note 16, at 331 n.5.

23 The so-called "plain meaning" approach to interpretation is helpfully outlined in $\mathrm{H}$. Read, J. MacDonald, J. Fordham \& W. Pierce, Materials on Legislation 790-815 (3d ed. 1973), It is rigorously analyzed and criticized in H. M. HART \& A. SACks, supra note 1 , at 1148-201.

Fuller ascribes to H.L.A. Hart the suggestion that legal rules may be understood and applied on the basis of examination of their language alone, rather than in conjunction with a search for their purposes. See Fuller, supra note 22, at 661-69. It is not certain, however, that such a view may fairly be attributed to Hart. Unfortunately, Professor Hart is not clear on this matter, as others have noted. See, e.g., R. WAsserstrom, The Judicial Decision 180 n.29 (1961). Hart discussed his idea of the "core of meaning" more recently in Hart, Problems of the Philosophy of Law, in 6 ENCYc. of PHILOsophy 264 (reprint ed. 1972).

2t See Baxter, supra note 9, at 6-7 \& n.15; Currie, Married Women's Contracts: A Study 
to regulate disputes having marginal or nonexistent relationships with the enacting state. Under a literal approach, statutes would be utterly indiscriminate in their coverage; the process of interpretation would provide no normative basis for making judgments about the appropriate extent of a statute's reach in mixed cases. Yet the essence of the choice problem is that just such judgments must be made. The functional theory of legislation and its companion purposive approach to interpretation permit the determination to be made on rational grounds. In the jargon of modern conflicts scholarship, the decision to apply a foreign state's local rule can be made only if that state is "interested" in the sense that the state's "policies," expressed by the rule's functions, would be advanced by application of the rule.

\section{The Processes of "Functional" Interpretation}

Functional choice-of-law analysis premises the existence of a state's "interest" upon a finding that the state's rule functionally is relevant to the immediate circumstances of the case. In determining whether a state is legitimately interested, then, the court must identify the functions of the rule whose application is advocated. Function, however, is a complex concept. ${ }^{25}$ Fundamentally different conceptions of state interest underlie alternative understandings of the term, and these conceptions may require resort to different sources in the process of ascertaining "functions." Modern scholarship has not yet refined this aspect of choice-of-law analysis. The respective positions taken on this question are discussed below as a way of introducing the more general problem of defining appropriate state interests.

\section{A. The Problem of "Hypothetical Purposes"}

How should the functions, or purposes, of domestic legal rules be identified? The position generally adopted by proponents of functional choice-of-law analysis is that "actual," rather than "hypothetical," functions must be identified..$^{26}$ That is, a court must

in Conflict-of-Laws Method, 25 U. CHI. L. REv. 227, 230-31 (1958), reprinted in B. CuRRIE, supra note 6 , at $77,81-82$.

${ }^{25}$ Uncertainty over the meaning of the function concept is reflected in other literature. Compare Raz, On the Functions of Law, in Oxrord Essays IN JuRISPRUDENCE 78, 299 (2d series A.W.B. Simpson ed. 1973), with Munzer, Retroactive Laws, 6 J. Legal Stud. 373, 392 n.24 (1977).

* See, e.g., R. WeINTRAUB, supra note 7, at 201-02, 242; Shapira, supra note 2, at 263. 
determine the functions that the rulemakers, legislators, or courts actually intended the rule to serve. A functional rationale unsupported by "authoritative statements" 27 of the rulemakers is merely hypothetical and cannot properly be considered by the court. The source materials that proponents of this view typically acknowledge as establishing actual functions include legislative history (if the rule involved is statutory), judicial expressions of the rule's functions, and scholarship on the subject. ${ }^{28}$

The objection to use of "hypothetical" functions is that "mere conjecture [by the court] is a judicial enterprise of dubious validity and little, if any, utility." ${ }^{29}$ Functional analysis by definition involves a search for particular facts-the objectives pursued by those enacting or developing the rule. A function hypothesized by the interpreting court is nothing more than the court's own theory imputed to the rulemakers. Only those objectives that can be attributed definitely to the rulemakers are properly called functions.

Restricting analysis to narrowly defined "actual functions" often means that only the original objectives of rules are considered. ${ }^{30}$ The legitimate source materials for such an inquiry, such as legislative history and prior judicial statements of the rule's functions, tend to provide only the original rationale for the rule. Legislative history of the rule, for example, is capable of revealing only the understandings of the rule held at the time of enactment. Other sources, such as subsequent judicial interpretations of the rule, conceivably may provide more current expressions of the rule's functions, but these often are not available. If there exists no subsequent authoritative expression, functions necessarily will be defined in terms of "intent."

Rules sometimes produce socially beneficial effects unrelated to

27 Shapira, supra note 2, at 263.

${ }^{2 x}$ See, e.g., R. Weintraub, supra note 7, at 202; Baade, The Case of the Disinterested Two States: Neumeier v. Kuehner, 1 Hofstra L. REv. 150, 152-56 (1973). The view that "purposes" include only those objectives that have been articulated by the rulemakers is expressed in a number of cases. See, e.g., Hardwick v. Bublitz, 253 Iowa 49, 54, 111 N.W.2d 309, 312 (1961); Neumeier v. Kuehner, 31 N.Y.2d 121, 286 N.E.2d 454, 335 N.Y.S.2d 64 (1972); Cipolla v. Shaposka, $439 \mathrm{~Pa} .563,568-78,267$ A.2d 854, 857-62 (1970) (Roberts, J., dissenting).

20 Shapira, supra note 2, at 263.

${ }^{30}$ See Baade, supra note 28, at 152-56 (discussing the Ontario guest statute in terms of its original purpose). Cf. Trautman, A Comment on Kell v. Henderson, 67 Colum. L. REv. 465, 468-72 (1967) (discussion of the subsequent judicial gloss placed on the Ontario guest statute). But see Trautman, Rule or Reason in Choice of Law: A Comment on Neumeier, 1 VT. L. REv. 1, 6 n.18 (1976) (accepting Baade's interpretation). This attitude, confining the "purposes" of rules to the original objectives, is evident also in a number of cases. See note 28 supra. 
their original purposes, however, and some writers have recognized that a narrow definition of functions may unduly restrict the inquiry to original objectives. They advocate a definition of functions that accounts for rules' contemporary effects, ${ }^{31}$ viewing such "contemporary functions" as relevant to the process of determining a state's interest. ${ }^{32}$

The two positions outlined here raise the problem of the appropriate treatment of a rule's contemporary beneficial effects when ascertaining whether a state is legitimately interested in the application of that rule. This controversy provides an opportunity to consider both the meaning of the term "function" and the rationale for taking into account in the interest-evaluation process the unanticipated or inadvertent effect. Finally, it leads to the basic question of which factor is ultimately determinative of the existence of a state interest: what the legislature or court intended by the rule or what the rule in fact achieves? This question becomes most acute when a rule is inefficacious, that is, when it fails to achieve its intended objectives.

\section{B. Functions, Reasons, and Effects}

When we analyze legal rules in terms of their functions, we normally refer to their social functions. ${ }^{33}$ All legal rules have social functions because they have and are intended to have social effects. We therefore define the social functions of a rule in terms of its social effects. Determining the function of a rule requires an investigation into the effects associated with the rule. But which effects should be considered? Are functions defined in terms of the rule's actual effects or only those effects that were intended? ${ }^{34}$ Experience with legal rules has demonstrated that the social effects actually produced by a rule may not be the same as those intended. ${ }^{35}$ More-

"See, e.g., Ratner, Choice of Law: Interest Analysis and Cost-Contribution, 47 S. CAL. L. REv. 817, 819 (1974); Sedler, supra note 13, at 197 n.100; Twerski, Book Review, 61 CoRnelL L. REv. 1045, 1057 (1976).

32 See, e.g., Sedler, supra note 13, at 198.

${ }^{37}$ A legal rule may have both normative and social functions or it may have only social functions. A norm is a standard for guiding human behavior. As such it provides reasons for actions or bases for evaluating or judging actions. Thus, if a rule were analyzed for its normative functions, we would be concerned with what actions the rule was intended to encourage and how these actions were guided by the consequences attached to the acts by the rule. See note 64 infra. By contrast, the social functions of legal rules, including those which are not norms, depend upon their social effects. See generally Raz, supra note 25 , at 278 .

"See text accompanying note 25 supra.

3s Identifying disjunctures between what a rule was intended to do and what it in fact does 
over, because of changes in the social and legal contexts in which rules operate, the effects of legal rules are not static. Before we can ascertain the "functions" of any particular rule, we must know which effects are relevant.

If function is associated with intended effects, the process of identifying the rule's functions would entail an investigation of the intentions, in the sense of actual objectives, of the person or group responsible for the rule. ${ }^{36}$ Alternatively, function might be defined as the social effects that actually follow from the rule: in explicitly causal terms, the social effects caused by the rule. This last formulation does not require an examination of any person's or groups' intention.

By distinguishing between these questions, two conceptions of the term "function" can be developed. One is etiological, in the sense that it identifies functions with the reasons or objectives that cause enactment or retention of a rule. The other is consequential, because it links the function of a rule to the consequences flowing from the rule. The etiological conception of "function" leads to a restricted and misconceived standard for ascertaining the existence of a state interest. The conception of function as consequential suggests a model-here termed the justificatory model-more suited to choiceof-law analysis. ${ }^{37}$

is particularly important in constitutional analysis. Under the aegis of substantive due process a statutory rule may be invalidated if the causal relationship between a statute and its intended objective is implausible or is affirmatively demonstrated to be missing. See Perry, Constitutional "Fairness": Notes on Equal Protection and Due Process, 63 VA. L. REv. 383, 392-98 (1977).

3s Asking what ends were sought by enacting the rule requires further clarification. When the issue is put in these terms, it is sometimes said that the interpreter is concerned with the rule's purpose and not its intention-intention is not relevant to this approach to interpretation. See, e.g., H. M. HART \& A. SACKs, supra note 1, at 1213-14. This view supposes that a gap exists between purpose and intention and that some theories of interpretation have mistakenly based the process on a search for intention. On this view, purpose places the search at an objective level, while intention is a subjective inquiry. Taken literally, this view makes no logical sense; the two concepts cannot be isolated from each other. Assuming, as this view does, that all legal rules are enacted with certain purposes in mind, then asking what those objectives are implicates intentional action and therefore leads to the further question of whose intention is relevant. What proponents of this view really object to is not the claim that intention is involved in the interpretation process but that intention be understood as requiring an investigation into the motives of the individual rulemakers. See Sedler, supra note 13 , at 197 . They want to resist confusing purpose with motive and to exclude consideration of motives, not intentions. There is a difference, after all, between asking, "What was $X$ seeking to accomplish?" and "What was $X$ 's motive?"

${ }^{37}$ This discussion should not be understood as suggesting that the consequential view of the function concept, rather than the etiological version, is analytically correct. I take no position on that question, which has generated disagreement among legal philosophers. See 


\section{The Etiological Model}

The functions of legal rules are sometimes defined as whatever the rules are designed to do. ${ }^{38}$ That definition implies intention by referring to the reasons for the rule's existence or retention. ${ }^{38}$ From this perspective it is not necessary to ask how the rule actually has operated-which intended effects were realized and which were not. One needs to know only what objectives the rule sought to accomplish, not what it did accomplish.

The etiological model, which defines functions according to the effects that the rule was originally intended to achieve, ${ }^{40}$ looks to the legislative proceedings or judicial rationales leading to the adoption of a statute or common-law rule, respectively. Identification of a rule's functions also involves viewing the rule in the social context within which it was adopted, comparing the rule with its antecedents, and determining the problem or "mischief" 41 that it was designed to correct. Whether dealing with statutory or common-law rules, however, the rulemakers' intention at the time the rule was adopted is the reference point in identifying the functions of the rule.

If functions are restricted to those effects intended by the rulemakers at the time of enactment, the functional account of a rule may be incomplete, particularly if the rule is not new. Since the time of its adoption, the rule may have had effects different from or in addition to those originally intended, and the rulemakers may or may not appreciate these effects. This possibility has led to a variation of the etiological model that permits cognizance of these later effects by incorporating a concept of imputed intention. This variation explains the continued existence of a rule by assuming a present intention of the rulemakers to achieve the rule's current effects. Even though the rulemakers have not spoken since the time of enactment, their failure to change the rule is construed as ap-

note 25 supra. The thesis is that for choice-of-law purposes, the consequential version is functionally sounder.

${ }^{33}$ Munzer explicitly takes this view. See Munzer, supra note 25, at 392.

3* Cf. P. Brest, Processes of Constitutional Decisionmaking 42 (1975) (discussing and distinguishing "intent" and "purpose").

1" This version is suggested by such statements as: "The whole aim of construction, as applied to a provision of the Constitution, is to discover the meaning, to ascertain and give effect to the intent, of its framers and the people who adopted it." Home Bldg. \& Loan Ass'n v. Blaisdell, 290 U.S. 398, 453 (1934) (Sutherland, J., dissenting) (citation omitted).

"The term is drawn from Heydon's Case, 76 Eng. Rep. 637, 638 (Exch. 1584). 
proval of the current effects. ${ }^{42}$ More precisely, current effects are the present rulemakers' reasons for keeping the rule. Thus, although functions are still defined etiologically, subsequent rather than original intention is used to explain the rule.

The concept of imputed intention considers rulemakers to be on notice of all contemporary effects of rules. The rulemakers thus make an implicit statement about rules when they do not repeal them. Carried to the extreme, this analysis finds that an unrepealed rule is designed to achieve all the effects in fact achieved. If function is taken to mean what the rulemakers actually want, however, the definition of functions in terms of actual effects may be inaccurate if the rulemakers are unaware of a contemporary effect and therefore do not actually desire it. A possible response is that if the rulemakers were aware of a beneficial effect, they surely would desire it. This response, however, involves a prediction or, more accurately, a hypothesis of the rulemakers' intentions, past or present. When rulemakers are completely silent with respect to a particular effect, we cannot say anything with certainty about their intentions regarding that effect; they may have an intention with regard to an effect, but we cannot always say what that intention is. ${ }^{43}$

The attempt to identify current effects with the etiological "functions" of rules is unpersuasive for still another reason. It fails to preserve the distinction between functions and accidents. 4 This distinction inheres in the etiological definition of function. The mere fact that some rule $r$ does something (has some effect) $e$ generally regarded as beneficial does not necessarily mean that $e$ is a function of $r$; rule $r$ may have caused or contributed to $e$ but if it did so by accident, it is not appropriate to say that $e$ is a function of $r$ under the etiological view. To illustrate, a soldier's belt buckle may stop a bullet from entering his abdomen, but it has that effect only fortuitously. We would not say on the basis of this effect that a belt buckle's functions include deflection of bullets. Even if this experience is repeated so often that we come to expect it, or at least are not surprised that the buckle stops bullets, it would seem wrong to say, "deflecting bullets is a function of the belt buckle." We would more likely say, "the buckle functioned as a bullet shield," but we would be using "function" only in a metaphorical sense. The repeated effect of stopping bullets cannot by itself make that a func-

12 See H. M. Hart \& A. SAcks, supra note 1, at 1203-15.

43 Id. at 1394-97.

"See Wright, Functions, 82 PhIL. Rev. 139 (1973). 
tion of buckles in an etiological sense, because buckles are not designed to stop bullets. Generally, functions are analyzed in terms of their ability to explain the existence of something. Saying that $f$ is a function of $s$ means that $s$ exists, at least in part, because $s$ does $f$, or that doing $f$ is a reason for $s$ 's existence. This etiological analysis of functions applies to the special case of the functions of legal rules just as to the general concept of function. ${ }^{45}$ Rule $r$ has as one of its functions $f$ only if $f$ is a reason for $r$ 's enactment. Things $e$ that $r$ can be said to do accidentally or incidentally are things to which $r$ contributes but which do not help to explain why $r$ was enacted; they cannot, therefore, properly be considered as functions of $r$.

If the etiological view preserves the distinction between functions and accidents, there will be some occasions when an actual effect of a rule cannot be counted as a function. Some effects are achieved inadvertently. An etiological account of the rule's functions will ignore these effects. Given this analysis of the concept of function, it becomes clear why some writers ${ }^{48}$ require that functions be ascertained on the basis of express articulations.

\section{The Justificatory Model}

The function concept sometimes is used in ways that import an altogether different meaning. ${ }^{47}$ Legal rules or doctrines sometimes are explained "functionally" not on the basis of the reasons for their enactment or current use, but rather on the basis of their operation or impact ${ }^{48}$ - that is, they may be explained in terms of what they do in fact rather than what they are supposed to do. This conception is purely causal and does not rest on the intentions of rulemakers. It does not distinguish between anticipated and unanticipated effects, between reasons and accidents. If a rule produces a certain effect, that effect is part of the rule's function.

Courts often do interpret statutes in light of current effects unanticipated by the rulemakers. ${ }^{99}$ "Giving effect to the rulemakers' intent" misdescribes this process..$^{50}$ Reliance on unanticipated benefi-

"s Id.

4 See note 26 supra and accompanying text.

1 See Boorse, Wright on Functions, 85 PHIL. Rev. 70 (1976).

** See, e.g., Scott, Standing in the Supreme Court-A Functional Analysis, 86 HARv. L. REv. 645, 669 (1973).

13 The discussion of new applications of old enactments in H. M. HART \& A. SACKS, supra note 1, at 1203-17, is especially helpful.

so Currie described the process in these terms:

It involves an attempt to ascertain what the legislature meant, in part by reference to 
cial effects takes the court beyond the level of ascertaining historical facts. Drawing on its common-law power, the court develops its own theory of reasons that justify the rule and looks to the current actual effects of the rule in developing that theory.

The process of interpreting a rule by determining whether it can be justified on the basis of its effects is not at all unusual. Sometimes lawyers must present newly developed reasons because original objectives no longer justify a rule in light of contemporary social conditions and needs or because these objectives are no longer consistent with existing social values. Those who wish to preserve a rule or to have it applied to a particular problem may choose to ignore the historical data on the original reasons, presenting instead a new construct of reasons. ${ }^{51}$ This process of interpretation is quite unlike the etiological analysis: the new reasons offered may fortuitously coincide with the rulemakers' intentions, but no necessary relationship exists between the two. ${ }^{52}$ The process does not rest on any supposition that the rulemakers were aware of these reasons in creating the rule or even that they would have regarded the reasons as arguments in favor of the rule. All that matters is that the reasons be considered as now justifying the rule..$^{53}$

Justification of any legal rule may proceed on a number of different levels. The common method of legal justification is to point out a rule's socially beneficial consequences, ${ }^{54}$ which provide persuasive

definitions that have been established in other contexts for terms employed in the statute, and in part by resort to such "legislative history" as may be available; beyond this, it involves an attempt to ascertain the legislative purpose, and to impute to the legislature an "intention" to include the marginal situation or not according to whether analysis indicates that inclusion would serve, or disserve, or be irrelevant to that purpose.

Currie \& Lieberman, supra note 16, at 2-3, reprinted in B. CuRRIE, supra note 6, at 377 (footnote omitted). See also R. Dickerson, The InTERPRETation and Application of Statutes 10 (1975); H. M. HART \& A. SAcKs, supra note 1, at 1225.

${ }^{31}$ This is often true, e.g., of constitutional interpretation, in which decisionmakers sometimes must determine whether changed conditions permit an interpretation that departs from the original understanding of a provision of the Constitution. See P. BREST, supra note 39, at $145-71$.

52 This discussion is not intended to dismiss legislative intent as meaningless in such instances, nor are the original reasons for the rule totally irrelevant. The point is instead that in tbis process of justification, the interpreter is not restricted to the original reasons. Perhaps it would be most accurate to describe the process as independent justification.

ss Whether one would agree or disagree with the proposition that the rule is justifiable on the reasons given, the crucial issue is whether the community would view the rule as so justifiable. Evidence of consensual support may be provided by other rules that clearly have been adopted for the same reasons, to achieve the same or similar goals.

s See Munzer, supra note 25, at 390-92. 
reasons for its acceptance and application. Thus, if we agree that $x, y$, and $z$ are socially beneficial states of affairs and that rule $r$ brings about or contributes to bringing about $x, y$, and $z$, we have found at least prima facie justification for rule $r .{ }^{55}$ We must recall, however, that while we may accept these effects as justifications for the rule, we cannot consider them functions in the etiological sense. The etiological definition necessarily encompasses design: ${ }^{56}$ to assert that $z$ is a function of rule $r$ is to say that doing $z$ is a reason $r$ exists, or that $r$ was adopted, at least in part, to do $z$.

\section{Shifting Justifications}

The distinction between justifications and etiological functions is illustrated by the phenomenon of shifting justifications for archaic or inefficacious rules. A rule may have been adopted for the purpose of achieving a particular effect, but subsequently fails to perform as anticipated. ${ }^{57}$ The rule's functional inefficacy means that its functions do not justify the rule. Similarly, even when a rule continues to serve its intended functions, these functions may not justify the rule's continued existence if they are no longer important or desirable in light of changed social conditions or attitudes. In each case, survival and continued acceptance of the rule indicate that its justification has shifted, and the new justification often will center on

ss See generally Held, Justification: Legal and Political, 86 Ethics 1 (1975).

st See text accompanying notes 38-39 supra.

${ }^{37}$ This is true of a number of rules frequently involved in choice-of-law cases, e.g., the guest statute. If some or most guest statutes were enacted "to protect insurance companies against claims which would necessitate an increase of motor vehicle insurance rates," Baade, supra note 28 , at 156 , empirical studies strongly suggest that guest statutes have little or no effect in this regard. See, e.g., Morris, Enterprise Liability and the Actuarial Process-The Insignificance of Foresight, 70 YALE L.J. 554, 574-77 (1961); Tipton, Florida's Automobile Guest Statute, 11 U. FLA. L. REv. 287, 306-07 (1958); Comment, Review of the Past, Preview of the Future: The Viability of Automobile Guest Statutes, 42 U. CiN. L. REv. 709, 721 (1973).

Dramshop statutes, which impose civil liability on bartenders who serve excessive amounts of alcohol to patrons who subsequently drive and cause injury to other persons, may be analyzed similarly. It is generally thought that such statutes are intended to promote greater highway safety by deterring bartenders from serving alcohol to intoxicated patrons. See Bernhard v. Harrah's Club, 16 Cal. 3d 313, 322, 546 P.2d 719, 725, 128 Cal. Rptr. 215, 221, cert. denied, 429 U.S. 859 (1976). But there are no empirical data corroborating this view of the deterrent effect. Comment, Driving Under the Influence of Alcohol: A Wisconsin Study, 1970 Wis. L. REv. 495, 510-14 (1970).

The putative deterrent effect of rules requiring full compensation for wrongful death, which are also frequently involved in multistate problems, has also been doubted by some commentators on the basis of empirical evidence. See Weintraub, supra note 4, at 154 (citing Little, A Theory and Empirical Study of What Deters Drinking Drivers, If, When, and Why, $23 \mathrm{AD}$. L. REv. 23, 50 (1970)). 
unanticipated beneficial effects.

Of course, the mere fact that the rule survives does not mean that it is either justifiable or functionally efficacious. Legislatures, courts, and the public may have simply overlooked the rule. It may be less efficient to abandon the rule formally than simply to allow it to fall into disuse. ${ }^{58} \mathrm{In}$ such instances rules may be considered discarded, although they actually have not been repealed. Nevertheless, the fact that a rule, inefficacious in terms of its functions, is retained and applied is some evidence that it is considered justifiable on different grounds. While rules' functions often may provide their justifications, an inquiry into a given rule's functions does not necessarily reveal its justifications. ${ }^{59}$

58 See Ehrlich \& Posner, An Economic Analysis of Legal Rulemaking, 3 J. Legal Stud. 257, 277-80 (1974) (discussing costs associated with altering legal rules).

39 The phenomenon of shifting justifications sometimes may result in analyses of interest that, while consciously adhering to the etiological concept of functions, in fact reach results more consistent with the justificatory model. The treatment of automobile guest statutes in choice-of-law cases illustrates this problem.

One of the assumptions commonly made by courts when addressing the interest of a state in the application of its guest statute is that one purpose of guest statutes is the reduction of automobile liability insurance rates. See, e.g., Pfau v. Trent Aluminum Co., 55 N.J. 511, 263 A.2d 129 (1970) (lowa guest statute); Cipolla v. Shaposka, 439 Pa. 563, 267 A.2d 854 (1970) (Delaware guest statute); Conklin v. Horner, 38 Wis. 2d 468, 157 N.W.2d 579 (1968) (Illinois guest statute). Thus, if a driver involved in an accident is a resident of a guest-statute state, or if the car involved is registered in that state, there is a legitimate functional basis for the application of the guest statute. See, e.g., Ingersoll v. Klein, 46 Ill. $2 d 42,262$ N.E.2d 593 (1970) (applying Illinois law); Vick v. Cochran, 316 So. 2d 242 (Miss. 1975) (applying Alabama guest statute).

However, not all guest statutes were enacted with the effect on the insurance rates for local drivers in mind. In some states guest statutes originated as common-law rules at a time when automobile liability insurance was not a significant consideration. See, e.g., Boggs v. Plybon, $157 \mathrm{Va} .30,160$ S.E. 77 (1931). The Virginia General Assembly subsequently enacted a guest statute codifying this decision. See 1938 VA. Acrs of ASSEMBLY ch. 285 (current version at VA. CODE ANN. $\$ 8.01-63$ (1977)). The Virginia court in Boggs followed the lead of Massaletti v. Fitzroy, 228 Mass. 487, 118 N.E. 168 (1917). Georgia courts also adopted the Massaletti rule, see Epps v. Parrish, 26 Ga. App. 399, 106 S.E. 297 (1921), but unlike Virginia and other states, Georgia failed to enact the rule in statutory form.

The rule of limited liability to gratuitous automobile passengers developed in these states as an extension of the well-established principle of the reduced duty of care that attached to gratuitous bailments, see Foster v. Essex Bank, 17 Mass. 479 (1821); Coggs v. Bernard, 2 Ld. Raym. 909, 92 Eng. Rep. 107 (K.B. 1703), and later to other sorts of social arrangements, such as gratuitous passage on horse-drawn vehicles. See West v. Poor, 196 Mass. 183, 81 N.E. 960 (1907). Eventually the doctrine expanded to cover the question of liability of automobile drivers to gratuitous passengers. See Massaletti v. Fitzroy, 228 Mass. 487, 118 N.E. 168 (1917).

The rationale for the rule's application in each new situation, including automobile accidents, remained the same, and this rationale did not include concern for insurance rates. Subsequently enacted in statutory form, the rule retained its common-law rationale. See 


\section{Application of the Justificatory Model to the Determination of State Regulatory Interests}

The distinction between the etiological model and the justificatory model is that the former looks solely at intent or purposes while the latter additionally examines the actual, current benefits of the rule at issue. The next step in the analysis is to employ the justificatory model in the determination of a state's interest in the rule. Three considerations are relevant to this analysis: (1) a rule's actual effect is a legitimate basis for a state interest; (2) actual effects must be susceptible to verification before reaching the conclusion that the state is interested; (3) even though a state may have a general interest in a rule's effect, if concurrent rules also achieve that effect and application of this rule to this controversy does not enhance the effect, application legitimately may be denied.

\section{A. Interest as Benefit}

It is a fundamental premise of contemporary functional choiceof-law theory that to the greatest extent possible states should be permitted to attain and enjoy beneficial social conditions. ${ }^{60}$ States reap the full benefit of their legal rules in domestic cases, and the diminution of that benefit in multistate cases ought to be held to the absolute minimum. Therefore, if we can benefit one state by allocating regulatory authority to it without harming another, we should do so because that allocation makes maximum use of the resource of regulatory authority.

We can benefit a state in two ways: first, by permitting it to pursue those social objectives on which it has consciously settled

generally Elliot, Degrees of Negligence, 6 S. CAL. L. REv. 91 (1933). At the time these guest statutes were enacted, automobile liability insurance had become a familiar institution, and it is conceivable that the change from common-law rule to statute was not simply a change in form but represented a reaction to greater concern over increasing insurance rates. The difficulty with this interpretation, however, is that insurance-related concerns appear neither in the legislative histories of these statutes nor in contemporaneous judicial interpretations. See Note, The Present Status of Automobile Guest Statutes, 59 CoRnell L. REv. 659, 663-65 (1974). It appears therefore that the functional rationale for many guest statutes had nothing to do with protection of the insurer or with reduction of insurance rates.

Thus, except when a guest statute can truly he said to have been directed at insurance concerns, as appears to be the case with Ontario's guest statute, see Baade, supra note 28 , at 152-56, such factors as the location of the insured risk would not he relevant in determining whether a guest statute jurisdiction has a functional interest in the application of its law. We can characterize the approach of courts that have emphasized such concerns when analyzing multistate guest-statute problems as inadvertently justificatory.

c See Baxter, supra note 9, at 10. 
and for which its rule was designed; ${ }^{61}$ second, by permitting the state to enjoy other social states of affairs to which its rule contributes, even though these effects were not among its objectives in adopting the rule and were wholly unanticipated. In the domestic case the state would realize both sorts of benefit, and there is no reason, other than impairment of the interests of another involved state, to deny it the equal value of its rule in the multistate case.

This premise in the method of allocating regulatory authority over multistate transactions gives full respect to the political rights of states, implicit in the full faith and credit clause of the federal Constitution, ${ }^{62}$ to pursue and enjoy social states of affairs that contribute to their collective welfare. Choice-of-law theory therefore must recognize a basis for allocating regulatory authority to a state whenever that allocation would further the state's goals or achieve some beneficial social effect that is consistent with the state's conception of public welfare. ${ }^{63} \mathrm{~A}$ conception of interest predicated exclusively on functions sometimes will ignore justifiable bases for granting a state authority to regulate a multistate transaction. An adequate model must consider those beneficial effects of a rule that currently justify it but that were not part of the reasons for its adoption.

Explaining and evaluating legal rules in terms of their justifications eliminates supposition and speculation in analyses of the policies expressed by conflicting rules. Factually inaccurate or manipulative speculations will be a genuine problem only if rules must be analyzed solely in terms of functions. Justifications, unlike functions, are not historical facts regarding legislative intentions and need not entail speculation or supposition about such events. The process of justification instead concerns the articulation of good reasons for accepting a rule. ${ }^{64}$

"It is made better off in this sense because its wishes are respected. Even if the rule does not effectively accomplish what the state intended it to, the state gains a benefit by having been given the opportunity to pursue its objectives through its own rule.

"2 U.S. Const. art. IV, $\$ 1$.

see note 53 supra and accompanying text.

4 This discussion has concentrated exclusively on one sort of justification, teleological reasons. Other, nonteleological reasons, however, may be relevant to evaluation of the bases on which a state might legitimately assert an interest in the application of its rule, such as fairness, both procedural and substantive. Such reasons, though arguably relevant, are frequently overlooked in choice-of-law analysis. In Hurtado v. Superior Court, 11 Cal. 3d 574, 522 P.2d 666, 114 Cal. Rptr. 106 (1974), for example, California's interest in the application of its rule on wrongful death damages might be predicated on the view that because the defendant caused the accident and consequent death of the plaintiffs' family member, fair- 


\section{B. Verification}

Valid justifications themselves must bear critical examination and verification. Claims of causal connection between rules and beneficial effects can and ought to be verified empirically when developing a rule's justificatory base. A significant lack of fit between a rule and an alleged consequence should dictate elimination of that "consequence" from consideration.

Socially beneficial conditions often, perhaps ordinarily, are attributable to more than one legal rule, but the lack of an exclusive one-to-one correlation between a beneficial condition and a particular rule should not disqualify the condition as a justificatory basis for an interest. If the rule actually would contribute, along with other rules, to achieving the beneficial condition, the state in a real sense would profit by application of its rule and therefore is legitimately interested. Sometimes, however, the connection between the application of a rule and the creation of a particular condition appears so attenuated, in view of the presence of other legal rules whose effect on that condition is more plausible, that the interest of the state is doubtful. ${ }^{65}$

ness requires that he compensate them for all their actual loss without the protection of a dollar limitation-a justification fundamentally different from the deterrence rationale on which the court relied. The fairness rationale reflects a deontological norm and, hecause it develops from a moral basis, should he regarded as intrinsically general in scope of application. Unlike rules that are premised and premisable solely on instrumental reasons, a rule that is based on fairness expresses a general conviction that applies to all agents. If something is right (fair) for one person or group of persons to do in a certain situation, then it is right (fair) for anyone similarly situated. See generally W. FrANKENA, Ethics 25, 27, 37 (2d ed. 1973). Using that view with respect to the California rule in Hurtado, California should be interested in its application regardless of its deterrent impact and regardless of the fact that it extends to non-Californians.

As a theoretical proposition there seems to be no necessary reason why a court may not conclude that a rule is justified on fairness considerations even though there is no evidence to suggest that the rule was consciously developed for fairness reasons. As a practical matter, however, a court might be tempted to say that its rule is based on a nonteleological reason, such as fairness, and conclude that the forum is interested in its application. While complete discussion of this problem is beyond the scope of this article, nonteleological justifications might be admitted as legitimate bases for state regulatory interests only when it appears that the rule was consciously developed for nonteleological reasons. One rule that might meet this criterion is the guest statute, which appears, at least in some states, to have been developed for reasons of substantive fairness. Considerations of insurance and the like have emerged after the statute's appearance. See note 59 supra.

For a discussion that reflects an awareness of this complication, see von Mehren, supra note 11. For a recent discussion of the different types of reasons that support common-law rules, see Summers, Two Types of Substantive Reasons: The Core of a Theory of Common-Law Justification, 63 CoRNELL L. REv. 707 (1978).

* Tbis seems to have been true of the California interest in Hurtado v. Superior Court, 11 Cal. 3d 574, 522 P.2d 666, 114 Cal. Rptr. 106 (1974). See note 83 infra. 
The verification process also should extend to a rule's intended effects, that is, its functions. Even if we can identify these functions with certainty, we should consider the extent of the rule's actual performance to determine if a gap exists between what was expected or designed and what was accomplished. ${ }^{66}$ It the rule has proven functionally inefficacious, we cannot justify it on the basis of its functions. If the rule has no other beneficial effect that would be furthered by its application in the immediate circumstances of the case, the state would not benefit through allocation to it of the regulatory authority. The rule may have been designed to reach just such a situation as is immediately at issue, but if it has not performed as anticipated in advancing the state's objective, there is no reason to give credit to that intention by admitting the existence of an interest.

It is important not to confuse the verification process with judicial weighing of conflicting state objectives. Functional choice-of-law theorists generally have opposed delegating to courts the authority to weigh objectives. ${ }^{67}$ In a broad sense, weighing the objectives of one state against those of another involves a pure value judgment by the court as to the relative worth of the objectives. The court allocates authority to regulate the multistate dispute to the state whose objectives it regards as more important. Verification involves the testing of a supposed objective to determine whether it is credible, that is, whether it accurately explains either the genesis or the operation of the rule. Conclusions about a policy's credibility in this sense are not value judgments, but factual determinations: they represent determinations of cause and effect rather than choices between competing values.

Functional choice-of-law theorists opposed to weighing objectives see no political justification for basing the choice of law upon the value judgments of courts. ${ }^{68}$ These theorists assert that the importance of objectives pursued by different states in a federal system ought not to be measured against one another on any absolute scale. Even if it were justifiable to do so, courts simply could not make such delicate and complex determinations accurately. ${ }^{69}$

${ }_{66}$ Contra, Currie \& Lieberman, supra note 16 , at 39 , reprinted in B. Curare, supra note 6 , at $376,413-14$.

${ }_{67}$ See, e.g., Baxter, supra note 9, at 18-19; Currie, supra note 12, at 176-78, reprinted in $\mathrm{B}$. Currie, supra note 6 , at 181-84.

6x This is the sense in which Baxter and, apparently, Currie opposed delegating the weighing responsibility to courts. See sources cited note 67 supra.

${ }^{69}$ See sources cited note 67 supra. 
The process of ascertaining the credibility of supposed justifications for rules does not violate this tenet of functional choice-of-law theory. Finding a justification not credible is an empirical observation that a rule does not achieve or contribute to the social condition that purportedly justifies it. By scrutinizing justifications in this way, we gain a clearer understanding of the operation of the rule and of the circumstances for its rational application.

\section{Impact of Concurrent Rules}

A benefit need not derive solely from a particular rule to serve as a basis for justification of that rule. All rules operating in conjunction or cumulatively to produce an effect may base their justifications thereon. A situation may arise, however, in which a state has an interest in attainment of a benefit, but not in application of a particular rule productive of that benefit. Other rules may also operate to produce substantially the same result without depriving a competing state of the benefit of its rule. Even if a rule is efficacious, we can justify its rejection when nonapplication will not result in a beneficial loss to the state. In these circumstances judicial nonapplication of a forum rule of an interested state and application of a competing foreign rule is a rational allocation of regulatory authority.

The familiar case of Bernkrant $v$. Fowler ${ }^{70}$ illustrates the implications that the existence of concurrent rules may have for interest analysis. An oral contract providing for cancellation of a debt by will, entered into by the parties in Nevada and valid under the laws of that state, was unenforceable under the Statute of Frauds of California, ${ }^{71}$ the decedent's domicile. The controversial aspect of the case concerns California's interest; Nevada plainly was interested in seeing its policy of enforcing consensual agreements prevail. ${ }^{22}$

The California court's decision to apply Nevada law in this situation is cited frequently as an example of the reduction of conflicts through reappraisal of forum interests in view of multistate policies. $^{73}$ The court plainly could have found California interested in application of its Statute of Frauds, with its underlying policy of

7e 55 Cal. 2d 588, 360 P.2d 906, 12 Cal. Rptr. 266 (1961).

"Cal. Civ. Code $\$ 1624(6)$ (West 1970).

72 Accord, Horowitz, The Law of Choice of Law in California-A Restatement, 21 U.C.L.A. L. REv. 719, 773 (1974).

73 A. von Mehren \& D. Trautman, supra note 7, at 241-44; Horowitz, supra note 72, at 772-74. 
protection of decedents' estates against baseless claims. The scope of that policy logically extends to all estates administered in California, and thus the functional conception of interest would indicate a California interest in the application of its statute.

Some commentators have viewed Justice Traynor's contrary conclusion as predicated on California's concern with facilitating interstate commercial transactions. ${ }^{74}$ This multistate concern, they assert, rendered the domestic policy of protecting estates less compelling, and thus the California policy of validating consensual transactions achieved a priority otherwise denied it. ${ }^{75}$ This explanation nevertheless assumes California did have a genuine interest in the application of its Statute of Frauds, ${ }^{76}$ but that interest was weaker than its validation interest. The difficulty with this solution, as one commentator has noted, is "the anomalous role of the court in weighing the strength of policy." "7

We can use the concept of interest as benefit, however, to explain the apparent anomaly of an interested forum declining to apply its own relevant rule. This permits us to focus on California's actual stake in the choice question-whether attainment of the benefit sought through its Statute of Frauds would have been furthered or hindered significantly by application or nonapplication of that statute. When we consider other rules shared by California and Nevada, it appears that failure to apply the Statute of Frauds did not entail sacrifice of the policy of protecting estates against false claims.

A large number of states do not have special statutes requiring a writing for contracts to make wills. ${ }^{78}$ Estates administered in these jurisdictions, however, are not left unprotected against the prospect

"See sources cited note 73 supra.

73 See sources cited note 73 supra.

${ }^{76}$ Professor Robert Sedler has argued that the policy of the California Statute of Frauds as to will contracts was inapplicable to the agreement in Bernkrant and would have been inapplicable even if the transaction had been wholly domestic. He argued that the agreement was treated not as a "true" contract to will, but instead as a commercial contract. See Sedler, Characterization, Identification of the Problem Area, and the Policy-Centered Conflict of Laws: An Exercise in Judicial Method, 2 Rut.-CAM. L.J. 8, 93 (1970); Sedier, supra note 13, at 196. An agreement, either written or oral, to forgive a debt by will may be uncertain from the perspective of whether to treat the transaction as inter vivos or testamentary, but its dispositive effect is certain.

$"$ Trautman, The Relation Between American Choice of Law and Federal Common Law, Law \& Contemp. Prob., Spring 1977, at 105, 107.

${ }_{78}$ B. Sparks, Contracts to Make Wills 48 (1956); Cavers, Oral Contracts to Provide by Will and the Choice-of-Law Process, in Perspectives of Law-Essays for Austin Wakeman ScotT 38-39 (1964). 
of spurious claims of oral agreements. Sections 4 and 7 of the general Statute of Frauds, adopted in most American jurisdictions, provide some measure of protection. ${ }^{79}$ Contracts to will, like other contracts, are subject to these provisions. Moreover, the general common-law rule that contracts to will must be proved by clear and convincing evidence provides considerable additional protection; ${ }^{80}$ although this last rule does not require a writing, it does share with the Statute of Frauds and the Wills Act the central concern that a testator be surrounded by some formalities of execution to shield the estate from false claims set up after the opportunity to answer has passed. Although a writing requirement may reinforce the requirement of clear and convincing proof, the additional protection actually afforded appears to be small. ${ }^{81}$

Both Nevada and California require that agreements to make wills satisfy the clear and convincing evidence requirement. ${ }^{82}$ It thus appears that the decision to reject California's statute did not expose the estate in Bernkrant to substantially greater danger than exists in wholly domestic cases when the statute is applied. Although California was interested in enjoying the benefits of its protective policy, it does not follow that its interest dictated application of its Statute of Frauds. Application of that statute in Bernkrant would have represented an inefficient allocation of regulatory authority, damaging Nevada's interest in enforcing consensual agreements without affording California any benefits materially different from those produced by concurrent rules.

To reiterate this last aspect of interest as benefit, we should not concede a state interest in the application of a particular rule if nonapplication would leave unimpaired other rules productive of the same beneficial effects. When the interests of another state clearly are affected by the decision, as in Bernkrant, the forum state should be indifferent to its own nonessential rule. ${ }^{83}$

7. B. SPAKKs, supra note 78, at 40 .

Id. at $24,48-49$.

"See id.:

[S]uch statutes should be regarded as supplemental to, not a substitute for, the rule that these contracts must be proved by clear and convincing evidence. If this rule is forgotten the statutory requirement will be insufficient to give adequate protection ... . If the clear and convincing rule is maintained estates are likely to find adequate protection ... whether or not they have the benefit of having additional provisions incorporated into the Statute of Frauds.

Id. at $48-49$.

"2 First Nat'l Bank v. Friednash, 72 Nev. 237, 302 P.2d 281 (1956).

* This analysis may suggest a basis for criticizing the conclusion in Hurtado v. Superior 


\section{Some Objections to the Thesis}

\section{A. The Burden of Ascertaining Effects}

The analysis of state regulatory interests in terms of actual effects may appear to complicate unduly an already complex process. Although a difficult task, ${ }^{84}$ the historical inquiry demanded by more conventional functional analysis at least has the merit of limiting a court's responsibility. It may seem unreasonable to ask in addition that courts identify and verify possible effects of rules whenever encountering choice-of-law problems. ${ }^{85}$

The suggested analysis, however, should not be understood to demand an empirical investigation in every case. The gains derived from such an inquiry would not justify the costs. Some cases will

Court, 11 Cal. 3d 574, 522 P.2d 666, 114 Cal. Rptr. 106 (1974), that California was interested in the application of its wrongful death damages rule on the basis of the deterrent effect of that rule. Whether or not deterrence was in fact a reason for adopting that rule, if failure to apply the rule would not affect the state's ability to enjoy that benefit (deterring negligent driving on California highways), the state should not be considered interested on the basis of deterrence. Other rules may foster deterrence of negligent driving. Persons driving in California are liable for unlimited damages on a cause of action for negligence, and if grossly negligent they may be criminally liable. These rules relate to the effect of deterrence of negligent driving as directly and as effectively as the full compensation for wrongful death rule, so that failure to apply that rule would not result in a significant reduction of the benefit to California of deterring negligent conduct.

* See Reese, Choice of Law: Rules or Approach, 57 CoRnell L. Rev. 315, 317-18 (1972); von Mehren, supra note 11, at 942 nn.37-38.

* Demanding that courts investigate the actual effects produced by the rules involved in a multistate problem may be viewed as unreasonable both because the necessary information may be unavailable to the court and to the litigants and because even if obtainable, the costs of obtaining that information would be excessive. These problems are accommodated to some extent by the limitation, discussed in text accompanying notes 86-88 infra, that the impactoriented analysis should be confined to cases where the empirical data on the effects of the rules are already available and relatively accessible. Also, the problems of inaccessibility and cost of obtaining information already are present under orthodox functional analysis. See note 84 supra and accompanying text. Even where the information on intention or purpose is available, obtaining and evaluating it on an individual basis is costly. Some commentators respond to these problems by virtual abandonment of the theory of functional analysis in particular circumstances. Where the functions of a rule cannot be ascertained with complete certainty, for example, one writer advocates simply withdrawing to the forum law. See Shapira, supra note 2 , at 263 . Other writers have denigrated more generally the significance of functional analysis, placing higher priority on the development of choice-of-law rules that admittedly are not always responsive to functional factors. See, e.g., Reese, supra note 84; Rosenberg, Comments on Reich v. Purcell, 15 U.C.L.A. L. REv. 551, 644 (1968). These two options, in fact, are occasionally posed as exhaustive of the available methods: one is forced to choose between a wholly nonformal, ad hoc "approach," and a formal system of choice-oflaw rules, according to which functional considerations are not necessarily determinative, especially if the functions cannot be easily ascertained. See Reese, supra note 84, at 315-17, 333-34. 
arise in which evidence of actual effects, as opposed to those intended or identified in "authoritative statements,"'s6 will become available. ${ }^{87}$ Choice-of-law theory should not preclude consideration of such information, ${ }^{88}$ nor should it predicate the legitimacy of this inquiry upon "endorsements" unearthed in statements of the rulemakers.

$m$ This discussion of the effects of rules admittedly has exaggerated and oversimplified the disjunction between what rules are intended to accomplish and what they in fact do. Nevertbeless there are inefficacious rules that fail, completely or substantially, to achieve their intended objectives, and rules occasionally do produce beneficial results other than anticipated. Thus, both parts of the basic assumption are sufficiently valid to make it worthwhile to consider at least the theoretical implications of these social facts, however uncertain their dimensions may be.

${ }^{87}$ Information about the impact of rules with regard to their ostensible functions is already available in a number of instances that recur in multistate litigation. Guest statutes and statutes providing full compensation for wrongful death, for example, have been empirically examined on several occasions, see notes 57, 59 supra. As empirical study of the effects of rules increases, the information necessary to implement the theoretical observations made here gradually will become available to courts and litigants.

s The adoption of narrowly drawn choice-of-law rules, urged by some observers, would foreclose consideration of this information. Professor Reese, for example, has recommended that in some areas useful choice-of-law rules may be developed. See Reese, supra note 84, at 325. Thus he supposes that with respect to a few isolated issues, one state will almost invariably be not only interested but "of greatest concern" because of a particular factual link, regardless of the content of its domestic rule. By identifying these circumstances, a choiceof-law rule may then be developed to resolve the conflict without any reference to the functions or effects of the competing domestic laws. One such group of issues that he suggests is ripe for resolution by precise, static rules involves immunities from tort liability. Id. at 327 . 28. For example, jurisdictions that are the common domiciles of guest passengers and drivers will be more interested than other involved jurisdictions, such as the state where the injury occurred, in nearly all cases. He recommends, therefore, a choice-of-law rule that where the parties to a tort action have a common domicile, the law of that state should be applied to determine liability and other issues as well. See id. However, even if we concede that all states having guest statutes have the policies of promoting hospitality by drivers and reducing insurance premiums, we cannot conclude that in the great majority of cases where passenger and driver are from the guest-statute state, the state will have anything genuinely at stake. The putative hospitality function of guest statutes provides a doubtful basis for interest since it seems unlikely that those statutes have any effect on the hospitality of drivers. At least, the connection is sufficiently doubtful to merit empirical verification before accepting this function as an interest foundation. The concern with insurance premiums is also of dubious effect on the guest statute jurisdiction's stake. See note 57 supra. In some instances, the insurance element may not be linked with the driver's domicile, if, for example, the automobile is garaged and insured elsewhere. But even if such situations are too rare to warrant rejection of an otherwise useful rule, the effect of nonapplication of the guest statute on the insurance premiums of drivers in that state is variable according to a variety of factors, especially the number of claims filed by passengers against resident drivers. Morris, supra note 57, at 574. Here again, the gap between function and effect may belie the legitimacy of the interest of the common domicile state. We simply need to know more about the impact of such rules before generalizing that states having particular contacts with the transaction are predominantly concerned. 


\section{B. Institutional Competence}

Legislatures can avail themselves of factfinding resources unavailable to courts and thus may be regarded as more competent than the judiciary in this sphere ${ }^{89}$ Enactment or retention ${ }^{90}$ of a statute presumably represents a legislative judgment that the statute is an effective means to an end. A court may appear to give insufficient weight to legislative factfinding capabilities, then, when it bases a decision to apply foreign law upon the inefficacy of its domestic rule..$^{91}$

Often, however, "more than enough factual information is generated without hearings; legislative facts abound and for every expert there is his equal and opposite number. Each has published widely; each researched extensively. Judges, then, often have as many useful legislative facts as do legislators." ${ }_{92}$ Indeed, as to the effects of legal rules, they may have more information. Charged with the duty of applying rules to a range of cases, judges may be uniquely qualified to observe a rule's operation and impact..$^{33}$

\section{Judicial Deference and Legislative Authority}

Courts ordinarily owe great deference to the means by which legislatures pursue legitimate ends. Far from adopting critical scrutiny of efficacy, judicial examinations of challenged statutes typically display a willingness to justify legislatively chosen "means" with tenuous "effects" and speculative "ends." Viewed against this

${ }^{80}$ Currie, The Verdict of Quiescent Years, 28 U. CH. L. REv. 258, 273 (1961), reprinted in B. Currie, supra note 6, at 584, 601-02. See also Cox, The Role of Congress in Constitutional Determinations, 40 U. CiN. L. Rev. 199, 228-29 (1971).

"But see H. M. HART \& A. SACKs, supra note 1, at 1394-97 (discussing the significance of legislative inaction).

"Of course, the relative competence of the judiciary is not an issue if the domestic rule at issue is a common-law rule.

"22 Wellington, Common Law Rules and Constitutional Double Standards: Some Notes on Adjudication, 83 YALE L.J. 221, 240 (1973).

"3 A court with much experience in the domestic application of a particular statute may have greater competence in evaluating its effects than the legislature that enacted it. For example, the lengthy citations of authority in Monarco v. Lo Greco, 35 Cal. 2d 621, 220 P.2d 737 (1950), attest to the court's extensive experience in applying, and creating exceptions to, Statute of Frauds requirements. This experience has been useful to the California court in cases dealing with the special provisions as to contracts to will, see Redke v. Silvertrust, 6 Cal. 3d 94, 490 P.2d 805, 98 Cal. Rptr. 293 (1971); and may help explain the court's response in Bernkrant v. Fowler, 55 Cal. 2d 588, 360 P.2d 906, 12 Cal. Rptr. 266 (1961). Bernkrant is discussed at notes 70-83 supra and accompanying text.

" See Williamson v. Lee Optical, 348 U.S. 483 (1955); Linde, Due Process of Lawmaking, 55 NEB. L. REv. 197, 204-05, 207-10 (1976); Perry, supra note 35, at 392-98. 
background, a judicial practice of scrutinizing the effects of forum law before deciding whether to apply it in a conflicts situation may appear to be an incursion on the legislature's authority.

The etiological model is predicated on judicial deference to legislative desires. ${ }^{95}$ The common view of the allocation of political responsibility in our system holds that legislatures both determine the social objectives to pursue ${ }^{96}$ and prescribe rules to achieve those objectives, and courts then interpret and enforce those rules. Consequently, the social objectives that legislatures pursue define "governmental interest," logical model restricts a court's conflicts inquiry to these objectives. Any other inquiry would entail impermissible judicial speculation about the rulemakers' actual objectives.

It is important to recall, however, the distinctive characteristics of the choice-of-law case. By definition the court has at least two rules to consider and must interpret each in making its decision. Although a state could relieve its courts of this task by explicitly prescribing (within constitutional bounds) the multistate operation of its laws, legislatures commonly phrase statutes in universal terms, ${ }^{98}$ leaving courts to determine the laws' reach in multistate conflicts.

In the absence of binding legislative direction, courts have great flexibility in articulating choice-of-law methodology. In doing so they act as common-law "places of initial resort," 99 devising solutions that may be modified or abrogated legislatively at a later time. ${ }^{100}$ The doctrine of deference to legislative authority therefore

2s See Shapira, supra note 2, at 263 (Courts must "articulate the actual policy objectives embodied in the legal prescriptions implicated in the confliets case at hand"; evaluations of a state's interest must be based on "an authoritative statement of the rule's policy rationale.").

" States have different levels of preference in regulating social activity. They do not desire all areas of authority equally; some areas are desired more than others. When an area of regulatory authority desired by a state is involved in a particular multistate transaction, that state is said to be "interested." The differences in objectives held by states are manifested in the differences in their legal rules. The objectives characteristically are pursued by favoring certain groups of persons over others, and legal rules, as instruments designed to achieve these objectives, express these preferernces.

"See Baxter, supra note 9, at 7-8.

" See note 24 supra and accompanying text.

" H. M. HaRT \& A. SAcKs, supra note 1, at 366 .

100 The same "initial resort" analysis has been offered as an explanation of modern constitutional decisions extending individual liberty:

[A] surprising amount of what passes as authoritative constitutional "interpretation" is best understood as something of a quite different order-a substructure of substan- 
need not preclude a choice methodology involving more rigorous means scrutiny than is appropriate in purely domestic cases.

The methodology advocated here aims for allocation of regulatory authority that maximizes benefits. This goal is not novel; it is also the normative basis of comparative impairment analysis, which seeks to resolve "true" conflicts by determining which state's social objectives would be frustrated more by nonapplication of its domestic rule. ${ }^{101}$ Indeed, the analysis suggested here can be viewed as an extension of that analysis. This article proposes that, when the actual effects on competing states of the application or nonapplication of their rules can be assessed, these effects rather than the rules' objectives should form the basis for any findings of "interest" or comparisons of "impairment." Thus, when a court can identify benefits that would accrue to a foreign state through application of its law and cannot find any identifiable detriment to the forum state, it may displace its own law without lack of deference and without implying that the forum law would not withstand challenge in a purely domestic case.

tive, procedural, and remedial rules drawing their inspiration and authority from, but not required by, various constitutional provisions; in short, a constitutional common law subject to amendment, modification, or even reversal by Congress.

Monaghan, The Supreme Court, 1974 Term-Foreword: Constitutional Common Law, 89 HaRv. L. REv. 1, 2-3 (1975). Monaghan advocates a more open assumption by the Supreme Court of the power to formulate "interstitial rules," id. at 28 , emphasizing that:

Congressional power to revise constitutional common law vitiates any objection that the Supreme Court, in fashioning interstitial rules, violates separation of powers principles vis-à-vis Congress. If Congress feels that the Court has overstepped permissible bounds, it can reverse a position taken by the Court whenever a rule goes beyond constitutional exegesis.

Id. at 34 .

${ }^{101}$ Baxter, supra note 9, at 6-18. The California Supreme Court has employed the principle of comparative impairment in two recent decisions. See Offshore Rental Co. v. Continental Oil Co., 22 Cal. 3d 157, 583 P.2d 721, 148 Cal. Rptr. 867 (1978); Bernhard v. Harrah's Club, 16 Cal. 3d 313, 546 P.2d 719, 128 Cal. Rptr. 215, cert. denied, 429 U.S. 859 (1976). See generally Johnson v. Johnson, 107 N.H. 30, 216 A.2d 781 (1966). In Johnson, a husband and wife domiciled in Massachusetts, a state that barred interspousal tort suits, were involved in an automobile accident in New Hampshire, where such suits were permitted. In an action against the husband brought by his wife in New Hampshire, the court declared its task to be "to determine whether the purposes of the relevant and applicable New Hampshire laws would be so seriously impaired by denying the Massachusetts plaintiff the right to sue her husband here that we should refuse to recognize this incident of a Massachusetts marital relationship." Id. at 32, 216 A.2d at 783. The court's decision to displace forum law turned on its conclusion that "[r]ecognition of the Massachusetts immunity will not render Massachusetts drivers less careful on our highways since their own and their wives' safety will still be jeopardized by carelessness on their part." Id. 


\section{Conclusion}

The development of a choice-of-law theory that facilitates the attainment by involved states of the maximum aggregate benefit has been impeded by the conventional definition of regulatory "interest" in terms of the functions of rules, as etiologically conceived. That such a definition is so widely accepted, however, should not be surprising. Adoption of that conception by contemporary choice-of-law theory is understandable, given the characterization of the choice-of-law process as interpretation and construction. The conception seems compelled by the purposive theory of interpretation. ${ }^{102}$ The choice-of-law problem, however, is not identical to the ordinary problem of interpretation, and the process of resolving multistate problems is not purely the ordinary process of construction and interpretation. Choice of law is concerned with the peculiar problem involving the allocation of the authority to regulate a multistate dispute.

A rational allocation of that resource requires a prior determination of whether either or both states involved in the transaction would be made worse off by being denied the authority to regulate according to its rule. The justificatory model facilitates this inquiry by examining the effects of a rule: a state is made worse off only if nonapplication of the rule involves the denial of an actual benefit to the state. To determine the existence of an actual benefit, the model contemplates that the effects of the rule must be verifiable and that concurrent state rules do not obviate the need for application in the particular case to achieve the benefit. In this manner actual state interests-rather than hypothetical, speculative, or unrealized objectives-will assume a proper place in the choice-oflaw decision.

102 "[T]o understand a law you must understand 'the disease of the commonwealth' it was appointed to cure . . . " L. FuLLER, supra note 22, at 83. 